\title{
ASSESSMENT OF EFFICIENCY OF USE OF AGRICULTURAL LAND: EXAMPLE OF SAMARA REGION
}

\author{
Velta Parsova ${ }^{1}$, Oksana Mamai ${ }^{2}$, Sergey Zudilin ${ }^{2}$ \\ ${ }^{1}$ Latvia University of Life Sciences and Technologies, Latvia; \\ ${ }^{2}$ Samara State Agricultural Academy, Russia \\ velta@parsova.lv, mamai_ov@ssaa.ru, zudilin_sn@mail.ru
}

\begin{abstract}
The land stock of the world is 13.4 thousand millions hectares or $26 \%$ of the surface of the Earth. Agricultural land appropriate for food production occupies 4.8 thousand millions hectares; arable land takes up only 1.4 thousand millions hectares or $30 \%$ of the agricultural land. For 100 years, the area of agricultural land increased only by 640 million hectares (less than $15 \%$ ), and in recent years it is declining. In Russia, area of the arable land is exploited on average at $70 \%$, while in the world the arable land has been used on average at $80 \%$. At present, the urgent problem is to increase the efficiency of use of land resources for stable development of all forms of agricultural enterprises, which have different status of ownership and management. Improvement of the use of natural resources, including land, in the agro-industrial complex is associated with the solution of two interrelated tasks: the development of a methodology for reliable assessment of the resource potential of agricultural land and the search for ways to use them most effectively. The opinions of many researchers about the proposed methods for assessing land resources often are essentially different. This leads to the fact that there are no unified established indicators for determining the efficiency of land use. Nevertheless, in the circumstances of market relations it is relevant and expedient to apply a single scientifically grounded system for assessing agricultural land for organizing its efficient use. The study showed that in Samara region about $72 \%$ of the arable land area is used for production of agricultural products, but it is necessary to find reserves to increase the efficiency of land use. Assessment of the efficiency of agricultural land use in the Samara region, a comparative analysis of the indicators of this region with the indicators of other subjects of the Russian Federation and the country in general created an opportunity to identify features of the use of agricultural land, highlighted problems and factors that determine the effectiveness of its use.
\end{abstract}

Keywords: agrarian sector, agricultural land, efficiency, farming, land stock.

\section{Introduction}

Agricultural land is the basis of the agrarian sector of the economy, where it occupies the largest proportion in the total area of land stock. Land resources are the subject and means of work in the agricultural sector, which play a very significant role. Rational use, assessment of the effectiveness of their involvement in the production cycle is an important component of ensuring the food security of the country and the region.

Increasing the efficiency of agricultural land use is an important component of improving the territorial organization of agriculture and the formation of hierarchical systems of the agrarian sector of the economy. In modern conditions the use of land is considered effective, when it increases the profit, amount of products from area unit, quality of products, fertility of soil, but reduces the production costs. It is very important that the environment is protected and the quality of life of the rural population is increasing. In the economic science great attention has been paid to the problem of increasing the efficiency of agricultural land use.

The economic concept of "efficiency" has a varied meaning, although its essence is in dialectical unity of two interrelated principles - the maximum result with the minimum costs necessary to obtain the result. According to V.A. Pokrovsky, only a comparison of the effect with the costs of its achievement characterizes the effectiveness [1]. Economic efficiency of the use of land resources in their work was considered by many scientists: V.V. Nemchenko, T.S. Proshlyakov, S.D. Cheremushkin, A.F. Mudretsov, L.S. Dudov, T.S. Khachaturov, V.A. Dobrynin, E.G. Lysenko, A.V. Tkach, A.A. Stepanov, R.V. Ilyukhina, B.I. Smagin, S. S. Sergeev, etc. According to V.A. Dobrynin, the economic efficiency of agricultural production should be understood, first of all, as the efficiency of land use, conversely, the economic efficiency of land use is the level of farming on it [2].

To follow the mentioned efficiency reveals the nature of the cause-and-effect relations of production and reflects not the result itself, but the price at which it was achieved. In this regard, efficiency often has been characterized by relative indicators, which are calculated on the basis of two groups of parameters - the results and costs. This, of course, does not exclude consideration in the 
system of performance indicators of absolute values of the initial parameters. Thus, the aim of this study is to identify peculiarities of use of agricultural land, problems and factors, which determine the effectiveness of its use in Samara region.

\section{Materials and methods}

The research methods include economic analysis and statistical data analysis. The study is based on the data of the Federal State Statistics Service, the territorial body of the Federal Service of State Statistics for the Samara Region, the Ministry of Agriculture of the Russian Federation, the Agriculture and Food Ministry of the Samara Region. The methodological basis of the study was made up of dialectical principles, methods of system analysis of economic phenomena: analysis and synthesis, the method of scientific abstraction, the economic-statistical method, the method of peer review and etc.

\section{Results and discussion}

Solving the problems of effective land use requires the organization of accounting and assessment of specific conditions of agricultural production for a separately processed land area. It is known that within the municipality territory and even within the territory of one separate farm the land can differ significantly in terms of natural and economic fertility, which affects the results of production [3].

The level of use of land usually is considered according to a real amount of products from the unit of land. However, these data do not disclose the activities of agrarian companies, because the results of land use depend not only on quality, but also on factors of intensification and organization of production. Therefore, there is a need to determine the estimated value of gross output, taking into account the economic assessment of the land. For comprehensive assessment of the use of land the system of indicators has to been used. The most common is the system of factorial and effective indicators. Among the factorial indicators, structural factors should be pointed out, which indicate: the following.

1. Level of development of the territory (1):

$$
L d=\frac{A a}{A t} \cdot 100 \%,
$$

where $L d-$ level of development, \%;

$A a$ - area of agricultural land, ha;

At - total area of farm, ha.

2. Level of plowing of agricultural land (2):

$$
L p=\frac{L a}{L f} \cdot 100 \%,
$$

where $L p-$ level of plowing of agricultural land, \%;

$L a-$ arable land, ha;

$L f-$ area of farmland, ha.

The main performance indicator of land use is the efficiency of land use by gross output, which is defined as the ratio of the value of gross agricultural output (crop production and livestock farming) to the area of agricultural land per 1 ha (roubles). Table 1 presents data on the assessment of the use of land in the Samara Region.

As it can be seen from Table 1, the main structural indicators of land use in the Samara region are higher than the average in Russia and the Volga Federal District. The level of development of the territory in the Samara region is about 6 times higher than in Russia and about 2 times higher than the average for the Volga Federal District. The level of tilled agricultural land in the Samara region is more by $43 \%$ than the average in Russia and by $19 \%$ more than the average in the Volga Federal District. However, in the Samara region there are reserves for increasing the efficiency of land use, since the level of the use of arable land is only $72 \%$, and because the fallow land occupies more than 104 thousand hectares [4]. 
It is necessary that the problems of effective land use in the agrarian sector are solved systematically focusing on the realization of both internal and external factors (Figure 1).

Table 1

Initial data for assessing the efficiency of land use (on 01.01.2017)

\begin{tabular}{|l|c|c|c|}
\hline \multicolumn{1}{|c|}{ Indicators } & $\begin{array}{c}\text { Russian } \\
\text { Federation }\end{array}$ & $\begin{array}{c}\text { Volga Federal } \\
\text { District }\end{array}$ & $\begin{array}{c}\text { Samara } \\
\text { Region }\end{array}$ \\
\hline Total area, million hectares & 1712.5 & 103.7 & 5.4 \\
\hline Area of agricultural land, million hectares & 222.0 & 55.1 & 4.0 \\
\hline Area of arable land, thousand hectares & 116271.4 & 36464 & 2858.4 \\
\hline Fallow land, thousand hectares & 4800.0 & 764.9 & 103.8 \\
\hline Total sown area, thousand hectares & 79581.0 & 23801.6 & 2050.4 \\
\hline $\begin{array}{l}\text { The cost of gross agricultural production, billion } \\
\text { roubles }\end{array}$ & 5505.8 & 1276.4 & 99.5 \\
\hline Level of development of the territory & 12.9 & 53.1 & 74.6 \\
\hline Level of tilled agricultural land & 35.8 & 43.2 & 51.3 \\
\hline Share of use of arable land & 68.4 & 65.3 & 71.7 \\
\hline $\begin{array}{l}\text { Efficiency of agricultural land use, thousand } \\
\text { roubles/ ha }\end{array}$ & 24.8 & 24.9 & 23.2 \\
\hline
\end{tabular}

\begin{tabular}{|c|c|}
\hline \multicolumn{2}{|c|}{ Conditions for effective land use } \\
\hline$\nabla$ & $\downarrow$ \\
\hline $\begin{array}{l}\text { - Internal organization of the territory; } \\
\text { - Specialization and concentration of } \\
\text { production; } \\
\text { - Increase of the economic fertility of soils; } \\
\text { - Selection of crops, varieties, breeds of } \\
\text { animals of intensive type; } \\
\text { - Organization of high quality production } \\
\text { processes in optimal terms; } \\
\text { - Motivation of workers; } \\
\text { - Interest of the commodity producer; } \\
\text { - Realization of land ownership rights, etc. }\end{array}$ & $\begin{array}{l}\text { 1. Natural and climatic conditions. } \\
\text { 2. Organizational and economic conditions: } \\
\text { - methods of state regulation of land } \\
\text { relations (monitoring, land cadastre, land } \\
\text { management, land control); } \\
\text { - economic policy of the state; } \\
\text { - financial and credit policy; } \\
\text { - tax policy; } \\
\text { - price policy; } \\
\text { - relationship between partners in the agro- } \\
\text { industrial complex at the local, regional and } \\
\text { international level; } \\
\text { - market regulation (situation on the land } \\
\text { market, land evaluation institutions, etc.). }\end{array}$ \\
\hline
\end{tabular}

Fig. 1. Conditions for effective land use in agricultural sector

Rational ecologically safe use of land resources primarily depends on the organization of agriculture and involves a number of tasks related to social programs, the development of livestock and the processing of agricultural products $[5 ; 6]$.

One of the most important tasks of modern farming is its biologisation and ecologization on the base of transition to adaptive landscape systems of farming and modern agrotechnologies in the circumstances of increasing of negative anthropogenic impact on the soil - processes of soil cover degradation, erosion, loss of humus $[7 ; 8]$.

In the Samara region the predominant soil is blackland (chernozem), the area of which is $98 \%$ of the arable land. The data on the dynamics of the humus content, which is an integrated index of soil fertility, for the period 1975-2010, testify about an obvious process of its decrease in the arable horizon of soil. For 25 years of farming the difference in the content of humus is $0.6-2.8 \%$. It corresponds to annual loss of humus reserves on 0.1-3.8 ton per hectare. The average of weighted content of humus in the region is $4.2 \%$, whereas in 1975-1985 it was $6.0 \%$. That means that there has been lost almost a third of fertility of soils. According to the data of the Agrochemical Service Station 
"Samarskaya", the area of the arable land with very low content of humus 1987-2010 increased by 99$124 \%$ or from 546 thousand hectares $(19 \%)$ to 1132 thousand hectares $(40.0 \%)$. Area of arable land with medium and high humus content has decreased, too [9]. Decrease of soil fertility has been caused by losses of organic matter, it leads to negative consequences - declines the quality of humus and agrophysical properties of soil, unavoidable reduction of yield arises, etc. Effective use of basic means of production, conservation of soil fertility and nature as a whole is possible only developing and introducing systems of farming, which are appropriate to the soil-climatic and economic conditions. Farming system is a program, the tool of competent field-cropping, which allows more efficient organization of production, rational use of land and machinery, achievements of science and competences [10]. Adaptive-landscape systems of farming include the basic elements that should become mandatory components of innovative technologies for cropping:

- cereal - fallow land crop rotations, oriented to the existing specialization of farms and maximum realization of the advantages of new technologies;

- minimal and differentiated systems of soil cultivation using combined soil-cultivating and sowing machines, as well as other machines applied to local soil-climatic conditions;

- resource-saving highly effective methods of fertilizer application combining with biological methods promoting reproduction of soil fertility;

- ecologically safe integrated system of plant protection against weeds, pests and diseases using effective drugs of new generation;

- system of machines based on wheeled tractors and combined machines of a new generation;

- new varieties of plants with increased plasticity, resistant to diseases and pests, with a high quality of grain, which are most adapted to modern technologies.

Instead of classical technologies based on traditional land treatment, new ones with new generation of combined machines for tillage, strictly differentiated economically and ecologically effective fertilizer application, as well as methods of crop protection, oriented to biological methods of reproduction of soil fertility have to be implemented. Research of the scientists of the Samara State Agricultural Academy shows that applying a rational approach to the formation of such technologies in the No-Till system, there are no fundamental restrictions to farming on chernozems in the Middle Transvolga [11].

In order to obtain high and stable results with low costs in farming, the whole complex of production processes is required to be carried out at the optimum time and qualitatively. It is possible, if there are highly qualified personnel, optimal organization of infrastructure, necessary machine system, high level of employee motivation, etc. However, the used domestic technologies are morally obsolete in comparison with the foreign analogous $[12 ; 13]$. In general, technical supply of agricultural machinery, counted on 100 hectares of the arable land in Samara region, is 12-15 times lower in comparison with the Western European countries [14]. It leads to decrease in farming productivity and increases the cost of production (Table 2).

In use of land resources qualification of employees plays an important role. During the period of reforms rapid decrease (by more than $30 \%$ ) of employees with higher and special technical education has taken place in the agrarian sector of the economy [15]. Also aging of the population as a result of the negative demographic situation in the countryside and the outflow of young people causes anxiety. In Russia, in general about $11 \%$ of the population is employed in agricultural sector. At the same time, work in collective agricultural enterprises is no more the main source of earnings, increasingly it is coming from personal subsidiary farms [16].

In the centre of all factors of effective land use there are people, their motives and interests. Realization of all conditions for efficient use of land resources is possible with the improvement of production relations. There is a need to change the management system of farming at all stages of the production process in accordance with the functional principle, which will allow to avoid collective irresponsibility [17]. Efficiency of land resources use depends on the influence of external conditions determined by the state policy in the field of regulation of land relations, finance and credit, price, tax institutes, as well as relations with partners in agro-industrial complex at the local, regional and international level [18]. 
Technical supply with tractors and combines in the Russian Federation

\begin{tabular}{|l|c|c|c|c|c|c|c|}
\hline \multirow{2}{*}{ Indicators } & \multicolumn{7}{|c|}{ Years } \\
\cline { 2 - 9 } & $\mathbf{1 9 9 0}$ & $\mathbf{1 9 9 5}$ & $\mathbf{2 0 0 0}$ & $\mathbf{2 0 0 5}$ & $\mathbf{2 0 1 0}$ & $\mathbf{2 0 1 5}$ & $\mathbf{2 0 1 6}$ \\
\hline $\begin{array}{l}\text { Number of tractors, pcs. per 1000 hectares } \\
\text { of arable land }\end{array}$ & 11 & 9 & 7 & 6 & 4 & 3 & 3 \\
\hline Load of arable land per tractor, ha & 95 & 108 & 135 & 181 & 236 & 307 & 305 \\
\hline $\begin{array}{l}\text { Machinery units per 1000 hectares of arable } \\
\text { land: }\end{array}$ & $\mathrm{X}$ & $\mathrm{X}$ & $\mathrm{X}$ & $\mathrm{X}$ & $\mathrm{X}$ & $\mathrm{X}$ & $\mathrm{X}$ \\
\hline - grain harvesters & 6.6 & 6 & 5 & 4 & 3 & 2 & 2 \\
\hline - corn harvesters & 12.4 & 15 & 8 & 5 & 1 & 0.0 & 0.0 \\
\hline - potato harvesters & 24.5 & 56 & 46 & 32 & 16 & 15 & 15 \\
\hline - flax harvesters & 21.8 & 34 & 32 & 22 & 24 & 14 & 13 \\
\hline $\begin{array}{l}\text { Area of arable land, hectares per one } \\
\text { harvester: }\end{array}$ & $\mathrm{X}$ & $\mathrm{X}$ & $\mathrm{X}$ & $\mathrm{X}$ & $\mathrm{X}$ & $\mathrm{X}$ & $\mathrm{X}$ \\
\hline - grain harvester & 152 & 173 & 198 & 253 & 327 & 422 & 425 \\
\hline - corn harvester & 80 & 68 & 120 & 215 & 817 & 2008 & 2497 \\
\hline - potato harvester & 41 & 18 & 22 & 31 & 62 & 67 & 65 \\
\hline - flax harvester & 46 & 29 & 31 & 46 & 42 & 70 & 75 \\
\hline
\end{tabular}

Many issues still remain unsolved in terms of common ownership of land. In order to create an effective mechanism, it is necessary to simplify the procedure for allocating separate land parcels instead of share in common ownership to create a simple system of registration the rights on land, to provide preferences for land surveying to landowners. At the same time, it is necessary to develop the federal Law on land leasehold, because leasehold relations have to be regulated. The system of taxation, penalties and compensation in agriculture should be based on the principle of leasehold payments. Determination of land tax rates have to be based on the level of natural fertility and ecological situation of land, but not so much on market indicators and the level of land management.

Among the external factors of effective land use in agrarian production the leading role is played by the financial and credit system and the tax system. Inaccessibility and high cost of commercial credits for agricultural enterprises initiate the need to reform financial and credit services for agroindustrial production.

With the aim of stabilizing the socio-economic situation in the countryside and increasing the amount of agricultural products, the government has developed a program "Development of the agroindustrial complex" [19]. State support is realised by subsidising of interest rates on investment credits, credits for development of production in personal subsidiary and peasant farms, machinery and equipment leasing systems, improvement of customs and tariff regulations, development of the network of consumer cooperatives, creation of the land mortgaging system, provision of affordable housing for young professionals in the countryside, etc. Of special interest is the direction on formation of the land mortgaging system, because it is the first proposed mechanism allowing to encumber the agricultural land with pledge on the basis of the Law "On the Mortgage". The land mortgaging system will help strengthen and develop the national credit and financial system of the agro-industrial complex, to attract extra budgetary financial resources to agribusiness, to involve reserves of agricultural land in real economic turnover, as well to form its real market value. The realisation of the mentioned tasks requires implementation of the set of organizational and economic measures, large-scale and coordinated actions at all levels. Thus, the main directions for increasing the efficiency of land use in agrarian production are the implementation of the intensive farming system with a clear agrarian state policy and regulatory support for reforms in the agrarian sector.

\section{Conclusions}

1. The conducted study shows that in the Samara region there are reserves for increasing the efficiency of land use, because the level of the use of arable land is only $72 \%$ and fallow land takes up about 104 thousand hectares. 
2. The solution of the problem of effective land use in the agrarian sector is possible only through the implementation of the system approach: maintenance of preservation and reproduction of soil fertility at simultaneous increase of productivity of agricultural crops; development and introduction of farming systems corresponding to the soil-climatic and economic conditions of farms; introduction of new technologies for cultivation of crops with minimal and zero tillage, using a new generation of combined tillage and sowing machines; increasing the attractiveness of the agricultural sector for the working-age population.

3. The study showed that it is important to regularly assess the effectiveness of land use, since its effective use is one of the important components of ensuring the food security of the country and the region.

\section{References}

[1] Покровский В.А. Повышение эффективности научных исследований и разработок (Increase the effectiveness of research and development). Moscow, 1978. 5 p. (In Russian).

[2] Добрынин В.А. Экономическая эффективность сельскохозяйственного производства в условиях перехода к рыночным отношениям (Economic efficiency of agricultural production in conditions of transition to market relations). Moscow, 1994. 46 p. (In Russian).

[3] Köstner B., Wenkel K.-O., Berg M., Bernhofer C., Gömann H., Weigel H.-J. Integrating regional climatology, ecology, and agronomy for impact analysis and climate change adaptation of German agriculture: An introduction to the LandCaRe2020 project. European Journal of Agronomy, vol. 52, 2014, pp. 1-10.

[4] Территориальный орган Федеральной службы государственной статистики по Самарской области (The territorial body of the Federal State Statistics Service for the Samara Region). [online] [10.03.2018]. Available at: http://samarastat.gks.ru/.

[5] Parsova V., Kapostins E. Land Policy in Latvia: Implementation and Evaluation of Results. Proceedings of the $7^{\text {th }}$ international scientific conference "RURAL DEVELOPMENT 2015: Towards the Transfer of Knowledge, Innovations and Social Progress", Aleksandras Stulginskis University (Lithuania), 2015, Kaunas, http://conf.rd.asu.lt/index.php/rd/article/view/79/53

[6] Кирюшин В.И. Теория адаптивно-ландшафтного земледелия и проектирование агроландшафтов (Theory of adaptive-landscape agriculture and the design of agro landscapes). Moscow, 2011. 443 p. (In Russian).

[7] Кирюшин В.И. Экологические основы проектирования сельскохозяйственных ландшафтов (Ecological basis for designing agricultural landscapes). St. Petersburg, 2018. 568 p. (In Russian).

[8] Semenda D, Semenda O. Assessment of ecological and economic efficiency of agricultural lands preservation. Environmental Economics, vol. 9(1), 2018, pp. 47-56.

[9] Зудилин С.Н., Зудилин А.С. Мониторинг плодородия черноземов Самарской области (Monitoring of fertility of chernozems in the Samara Region). Problems of development of agroindustrial complex of the region, № 1-1 (25), 2016, pp. 37-40. (In Russian).

[10] Dury J., Schaller N., Garcia F., Reynaud A., Bergez J.E. Models to support cropping plan and crop rotation decisions. A review. Agronomy for Sustainable Development, vol. 32, 2012, pp. 567-580.

[11]Корчагин В.А., Шевченко С.Н., Зудилин С.Н., Горянин О.И. Инновационные технологии возделывания полевых культур в АПК Самарской области (Innovative technologies of cultivation of field crops in agrarian and industrial complex of the Samara region). Kinel, 2014. 192 p. (In Russian).

[12] Kopiks N., Viesturs D.. Investigations in the Suitability of a Fleet of Combines for timely Harvesting. Proceedings of 15th International Scientific Conference "Engineering for Rural Development", Vol. 15, Jelgava, 2016, pp. 681-685.

[13] Viesturs D., Kopiks N. Trends in development of tractor fleet in Latvia Proceedings of 16th International Scientific Conference "Engineering for Rural Development, Vol. 16, Jelgava, 2017, pp. 534-539.

[14] Федеральная служба государственной статистики (Federal State Statistics Service). [online] [10.03.2018]. Available at: http://www.gks.ru/. 
[15] Мамай О.В., Мамай И.Н. Теоретические основы инновационного развития аграрного сектора региональной экономики (Theoretical bases of innovative development of agrarian sector of regional economy). Kinel, 2015. 166 p. (In Russian).

[16] Fiszbein A., Kanbur R., Yemtsov, R. Social protection and poverty reduction: Global patterns and some targets. World Development, vol. 61(1), 2014, pp. 167-177.

[17]Волконская А.Г., Галенко, Н.Н., Курлыков О.И. Управленческие проблемы аграрного сектора (Management problems of the agricultural sector. Proceedings of International conference "Actual problems of agrarian science and ways to solve them", Kinel, 2016, pp. 756-759. (In Russian).

[18]Галенко Н.Н. Уголовная ответственность за нарушение земельного законодательства (Criminal liability for violation of land legislation). Proceedings of IV International conference "Modern economy: ensuring food security", Kinel, 2017, pp. 67-71. (In Russian).

[19]Государственная программа развития сельского хозяйства и регулирования рынков сельскохозяйственной продукции, сырья и продовольствия на 2013-2020 годы (State program for the development of agriculture and regulation of markets for agricultural products, raw materials and food for 2013-2020). [online] [10.03.2018]. Available at: http://government.ru/programs/208/events/. 